\title{
JENIS-JENIS STRATEGI PERBANKAN SYARIAH
}

Mata Kuliah : Manajemen Strategi Perbankan Syariah

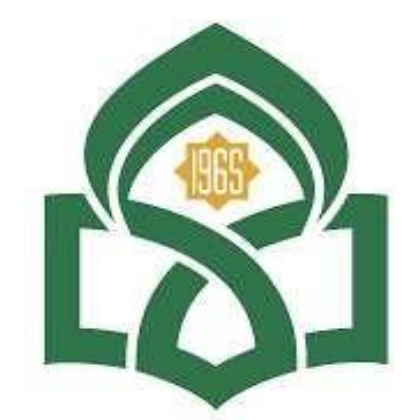

UNIVERSITAS ISLAM NEGERI

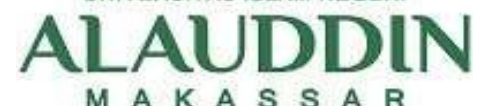

$M A K A S S A R$

Di susun oleh:

Kelompok 3:

Dewi Mardiany

$\underline{\text { Safitiryani Ridwan }}$

Firmansyah Syarifuddin $\underline{90500118013}$

$\underline{90500118006}$

$\underline{90500118007}$

Jurusan Perbankan Syariah

Fakultas Ekonomi Dan Bisnis Islam

Universitas Islam Negeri Alauddin Makassar 


\section{KATA PENGANTAR}

Assalamualaikum Warahmatullahi Wabarakatuh.

Puji syukur senantiasa kami haturkan kehadirat Allah SWT. Atas rahmat serta karunia-Nya sehingga kami dapat menyelesaikan makalah "Jenis-Jenis Manejemen Strategi” dengan baik. Makalah ini dibuat sebagai syarat pemenuhan tugas yang di berikan oleh dosen manajemen strategi.

Kami sangat berterima kasih kepada dosen mata kuliah manajemen strategi yang telah memberikan tugas kelompok untuk membuat makalah manajemen strategi. Kami berharap dengan adanya makalah ini dapat memberi manfaat bagi para pembaca untuk menambah wawasan dan pengetahuan tentang jenis-jenis manajemen strategi.

Wassalamualaikum Warahmatullahi Wabarakatuh. 


\section{DAFTAR ISI}

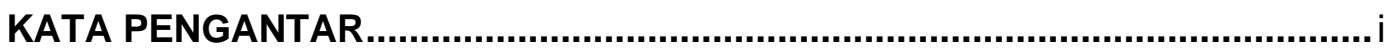

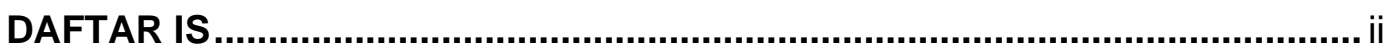

\section{BAB I PENDAHULUAN}
A. Latar Belakang
B. Rumusan Masalah 1
C. Tujuan Masalah 1

\section{BAB II PEMBAHASAN}
A. Pengertian Strategi Pemasaran 2
B. Jenis - jenis manajemen pemasaran 3
C. Bentuk - bentuk manajeman pemasaran 7

\section{BAB III PENUTUP}

A. Kesimpulan 9

\section{DAFTAR PUSTAKA}




\section{BAB 1}

\section{PENDAHULUAN}

\section{A. Latar Belakang Masalah}

Bank Syariah adalah bank yang dijalankan dengan prinsip hukum islam dalam kegiatan operasional nya. Di indoneesia sendiri sudah banyak bank syariah yang berdiri sejak lama namun masyarakat indonesia lebih cenderung menggunakan bank konvensional sebagai sarana mereka dalam bertransaksi perbankan yang dikarenakan mereka beranggapan bahwa bank konvensional lebih efisien dan mudah dalam bertransaksi.

Dengan alasan tersebut sejumlah bank syariah segera melakukan pemasaran yang mana mereka mengenalkan produk di bank syariah kepada para nasabah guna memenuhi tingkat kepuasan para nasabah dalam bertransaksi. Banyak konsep pemasaran yang di gunakan oleh sejumlah bank syariah selama mereka tetap menjalankan Corporate Ethical Edentity ( Identitas Etik Perusahaan),untuk itu sejumlah bank syariah menerapkan sejumlah strategi pemasaran guna menarik minat nasabah agar beralih ke bank syariah.।

\section{B. Rumusan Masalah}

1. Apa itu manajemen strategi?

2. Apa sajakah jenis-jenis manajemen strategi?

3. Apa sajakah bentuk-bentuk manajemen strategi?

\section{Tujuan Masalah}

1. Untuk mengetahui definisi manajemen strategi

2. Untuk mengetahui jenis-jenis manajmen strategi

3. Untuk mengetahui bentuk - bentuk manajemen strategi 


\section{BAB II}

\section{PEMBAHASAN}

\section{A. Definisi Manejemen Strategi}

Suatu strategi perusahaan (company's strategy) didefinisikan sebagai "rencana permainan" (game plan) yang dilakukan oleh manajemen untuk memposisikan perusahaan di dalam arena pasar yang dipilih supaya dapat memenangkan kompetisi, memuaskan pelanggannya dan mencapai kinerja bisnis yang baik. ${ }^{1}$

Strategi menurut Porter yang dikutip oleh Yosal Iriantara diartikan sebagai "formula berbasis luas mengenai cara bisnis bersaing, tujuan apa yang ingin dicapai, dan kebijakan apa yang diperlukan untuk mencapai tujuan tersebut. Hakikat perumusan strategi yang kompetitif adalah mengaitkan organisasi dengan lingkungannya". 2

Manajemen strategi adalah serangkaian keputusan dan tindakan manajerial yang menentukan kinerja perusahaan dalam jangka panjang. Manajemen strategi meliputi pengamatan lingkungan, perumusan strategi (perencanaan strategi atau perencanaan jangka panjang), implementasi strategi dan evaluasi serta pengendalian. ${ }^{3}$ Manajemen strategi menekankan pada pengamatan dan evaluasi peluang dan ancaman lingkungan dengan melihat kekuatan dan kelemahan perusahaan. ${ }^{4}$

Dari beberapa pengertian diatas dapat diambil kesimpulan bahwa manajemen strategi merupakan suatu proses yang dilakukan oleh manajemen dengan mengacu pada ketetapan yang telah ditetapkan sebelumnya dalam rangka untuk mencapai tujuan. Dengan kata lain manajemen strategi dapat diartikan sebagai sebuah seni dan ilmu dalam hal suatu rencana yang disusun dan dikelola dengan memperhitungkan berbagai sisi dengan tujuan memberikan dampak positif bagi organisasi secara jangka panjang.

\footnotetext{
1 Jogiyanto, Sistem Informasi Strategik (Yogyakarta: Andi, 2005), 32.

${ }^{2}$ Yosal Iriantara, Manajemen Strategis Public Relations (Jakarta: Ghalia Indonesia, 2004), 12.

${ }^{3}$ Gregory G. Dess and G. T. Lumpkin, Strategic Management: Creating Competitive Advantage (Boston: McGraw Hill-Irwin, 2003).

4 J. David Hunger dan Thomas L. Wheelen, Manajemen Strategis (Yogyakarta: Andi, 1996), 4.
} 


\section{B. Jenis - Jenis Strategi Perbankan Syariah}

1. Strategi Perbankan Syariah Dari Sisi Sumber Daya Manusia (SDM)

Sumber daya manusia atau biasa kita kenal dengan istilah SDM, adalah salah satu aspek didalam maajemen yang sangat penting. ${ }^{5}$ Peran sentral SDM didalam sistem manajemen dan perekonomian sangat mempengaruhi bagaimana perkembangan sebuah organisasi atau perusahaan. Tanpa SDM yang memadai, seluruh kegiatan operasional perusahaan akan terhambat. ${ }^{6}$ Dengan demikian, SDM harus dapat berkompetisi dan bersaing secara ketat dengan SDM lain agar muncul SDM yang unggul dan berkualitas.

Pengembangan SDM adalah salah satu cara yang sangat efektif dalam menghadapi tantangan dan masalah yang mungkin akan muncul dalam MEA. ${ }^{7}$ Perkembangan SDM dianggap sangat penting dilakukan karena melalui pengembangan pelaku kegiatan yang ada akan dapat meminimalisir ketergantungan organisasi pada penggunaan tenaga-tenaga ahli diluar organisasi. Menurut Ibrahim (2006) dan Handoko (2001), hal ini menjadi salah satu kelemahan dari perkembangan bank syariah di Indonesia.

Keberhasilan pengembangan bank syariah pada level mikro sangat ditentukan oleh kualitas manajemen dan tingkat pengetahuan serta keterampilan pengelola bank. ${ }^{8}$ Oleh karena itu, kualitas sumber daya manusia harus terus ditingkatkan baik pengetahuan tentang manajemen perbankan maupun pengetahun tentang syariah perbankan melalui pelatihan. Pelatihan ini, tidak hanya diberikan kepada level pimpinan saja, tetapi juga semua orang di lingkungan bank syariah mulai dari operator, customer service, direksi sampai pemilik, sehingga mereka lebih ahli dan bisa berfungsi sebagai sosialisator ataupun edukator yang baik tentang perbankan syariah di masyarakat.

2. Strategi Perbankan Syariah Dari Sisi Keuangan

Perbankan syariah menerapkan bagi hasil dan risiko antara penyedia dana (investor) dengan pengguna dana (pengusaha). Mirip dengan perbankan konvensional, tingkat keuntungan yang maksimum yang sesuai dengan nilai-nilai syariah juga harus diperhatikan agar pihak-pihak yang terlibat dapat menikmati keuntungan tersebut.

\footnotetext{
${ }^{5}$ Edi Suharto. 2006. Membangun Masyarakat Memberdayakan Rakyat. Bandung: PT Refika Aditama

${ }^{6}$ Hasibuan, Malayu S. P. 2000. Manajemen Sumber Daya Manusia. Bumi Aksara: Jakarta.

${ }^{7}$ Sondang P. Siagian. 2006. Manajemen Sumber Daya Manusia. Edisi Pertama. Bumi Aksara: Jakarta.

${ }^{8}$ Asnaini. 2008. Pengembangan Mutu SDM Perbankan Syariah: Sebagai Upaya Pengembangan Ekonomi islam. La_Riba, Jurnal Ekonomi Islam. Vol.II, No.1: pp. 51-68.
} 
Demikian pula bila terjadi kerugian, pihak-pihak yang terlibat turut menanggungnya. Di samping itu, perbankan syariah mengelola zakat, menghindari transaksi-transaksi yang berkaitan dengan barang-barang yang haram serta mengandung unsur-unsur maisir, gharar dan riba.

Dalam perbankan konvensional bank menggunakan uang tabungan untuk dipinjamkan kepada para debitur baik individu maupun pengusaha. Keuntungan diperoleh dari selisih antara bunga yang dikenakan kepada debitur dengan bunga yang dibayarkan kepada para penabung.

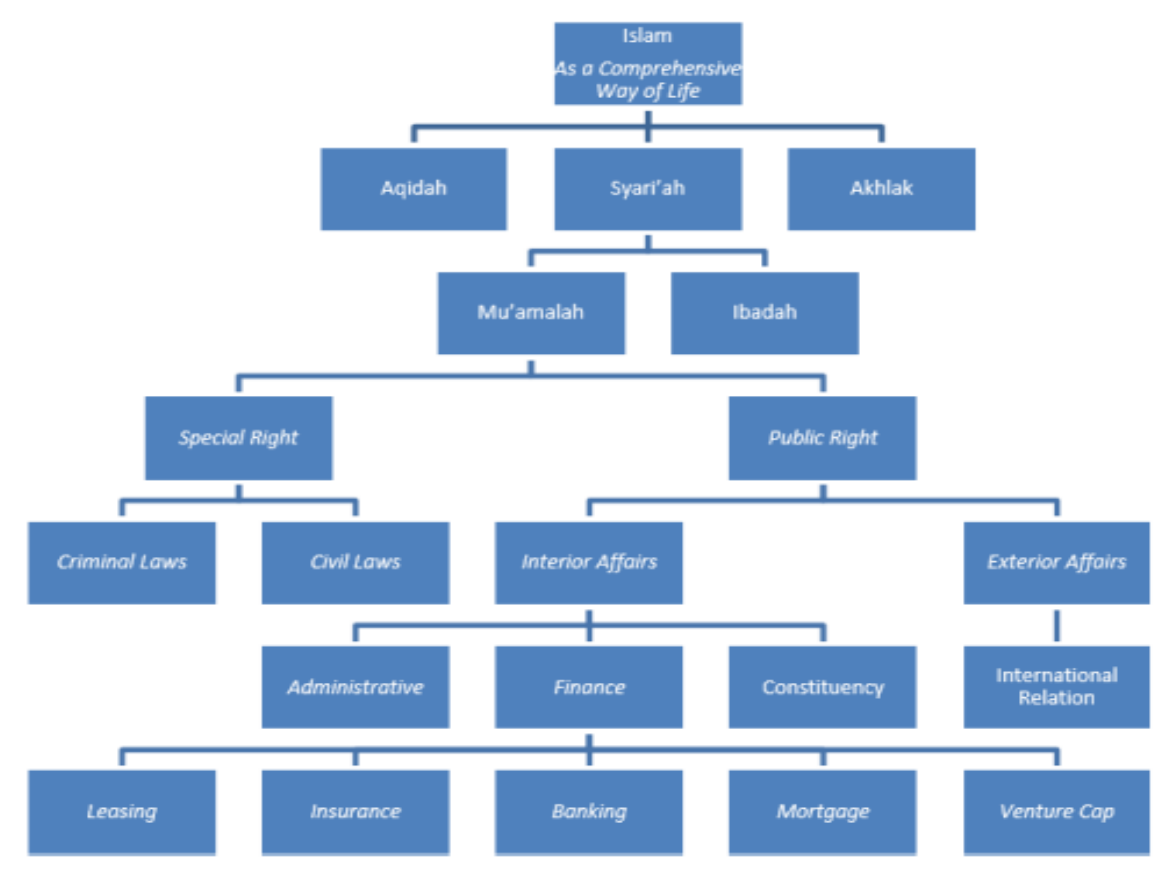

Gambar 7 Hubungan Keuangan Ekonomi Syariah dengan Aspek Rasional Realitas Ekonomi

Sumber: BI, 2017

Dari bagan di atas, terlihat bahwa manajemen keuangan atau ekonomi syariah juga berkaitan dengan aspek-aspek rasional ekonomi sebagaimana menjadi fokus ekonomi konvensional. Sehingga nilai Islam bukan merupakan aspek yang terpisah sama sekali dari aspek rasional realitas ekonomi. Kedua-duanya sangat terkait, pada kenyataannya. Oleh karena itu, kita maklum bahwa manajemen keuangan atau ekonomi syariah dikatakan juga bekerja mewujudkan motif/prinsip ekonomi, yaitu 
mencapai keuntungan yang sebesarbesarnya dengan tenaga yang sekecil-kecilnya ${ }^{9}$ sekalipun tidak absolut sama halnya dengan praktik motif ekonomi tersebut dalam realitasnya.

\section{Strategi Perbankan Syariah Dari Aspek Pemasaran}

Pemasaran adalah merupakan suatu proses sosial yang di dalamnya individu dan kelompok mendapatkan apa yang mereka butuhkan dan inginkan dengan menciptakan, menawarkan, dan secara bebas mempertukarkan produk yang bernilai dengan pihak lain. Tujuan pemasaran itu sendiri adalah mengetahui dan memahami pelanggan sedemikian rupa sehingga produk atau jsaa itu cocok dengan pelanggan. Bauran pemasaran merupakan variable-variabel terkendali yang digabungkan untuk menghasilkan tanggapan yang diharapkan dari pasarsasaran. Dan untuk usaha jasa terdapat 7 unsur marketing mix (Marketing Mix-7p) yaitu: Produk, Price, Promotion, Place, Partisipant, Proses, Dan Physical Evidence.

Menurut Kotler (2000:22), konsep pemasaran adalah kunci untuk mencapai tujuan organisasi yang ditetapkan yaitu perusahaan tersebut harus menjadi lebih efektif dibandingkan para pesaing dalam menciptakan, menyerahkan, dan mengakomodasikan nilai pelanggan kepada pasar sasaran yang dipilih. Definisi di atas ada empat gagasan dasar yang terkandung di dalamnya yaitu:

a. Pasar sasaran Suatu perusahaan belum tentu dapat berkembang dengan baik, tapi banyak perusahaan yang dapat mencapai apa yang menjadi targetnya dalam mengelola perusahaan dengan menentukan pasar sasarannya.

b. Kebutuhan pelanggan Berbagai kebutuhan pelanggan yang tidak selalu sederhana, perusahaan harus dapat meramalkan apa yang akan menjadi kebutuhan konsumen di masa yang akan datang.

c. Pemasaran terpadu Terjadi adanya kerjasama antara perusahaan dengan departemen terkait untuk melayani kepentingan pelanggan. Agar pemasaran dapat berjalan dengan maksimal untuk melayani kebutuhan pelanggan secara bersama.

d. Kemampuan menghasilkan laba Tujuan yang terakhir dari kosep pemasaran adalah membantu organisasi dalam mencapai tujuannya. Sebagian besar perusahaan tujuan utamanya adalah hanya untuk mendapatkan laba. Akan tetapi, di

\footnotetext{
${ }^{9}$ Andriansyah, Yuli. 2006. Kinerja Keuangan Perbankan Syariah di Indonesia dan Kontribusinya bagi Pembangunan Nasional. Jurnal Ekonomi Islam.Vol. 3, No. 2 : hal. 182-196.
} 
sini tidak hanya mengutamakan laba saja melainkan mendapatkan laba sebagai akibat dari kepuasan yang diperoleh konsumen dibanding dari pesaingan.

Pada prinsipnya strategi pemasaran memberikan arah dalam kaitannya dengan variabel-variabel seperti segmentasi pasar, identifikasi pasar sasaran, posisi, elemen bauran pemasaran dan biaya pemasaran, dimana strategi pemasaran merupakan bagian integral dari strategi bisnis yang memberikan arah bagi semua fungsi manajemen suatu organisasi. ${ }^{10}$

Setiap perusahaan mengarahkan kegiatan usahanya untuk menghasilkan produk yang dapat memberikan kepuasan kepada konsumen sehingga dalam jangka waktu dan dalam jumlah produk tertentu dapat diperoleh keuntungan seperti yang diharapkan. Melalui produk yang dihasilkannya, perusahaan menciptakan, membina dan mempertahankan kepercayaan akan produk tersebut. Keberhasilan suatu perusahaan dapat ditentukan oleh ketepatan produsen dalam memberikan kepuasan dan sasaran konsumen yang ditentukannya, dimana usahausaha pemasaran diarahkan kepada konsumen yang ditujukan sebagai sasaran pasarnya.

\section{Strategi Perbankan Syariah Dari Aspek Produksi Layanan Jasa}

Perbedaan mendasar antara perbankan konvensional dan perbankan syariah yang didasarkan pada bunga dan bagi hasil ternyata tidak cukup mempertahankan loyalitas nasabah. Ada banyak faktor yang bisa dijadikan alasan nasabah untuk tetap loyal pada lembaga keuangan. Salah satunya adalah pelayanan prima (service excellence). Pelayanan ini sangat penting untuk mempertahankan dan menarik nasabah lebih banyak.

Service excellence adalah kepedulian kepada pelanggan dengan memberikan layanan terbaik untuk memfasilitasi kemudahan, pemenuhan kebutuhan dan mewujudkan kepuasannya, agar mereka selalu loyal kepada perusahaan (Lovelock dan Wirtz, 2004). Pelayanan yang baik menjadi penting sebagai alat promosi bagi calon nasabah. Service excellence di bank bisa dikatakan sebagai pelayanan untuk memberikan kepuasan kepada nasabah agar mereka mendapatkan apa yang

\footnotetext{
${ }^{10}$ Asri Fajar Sari (2012). "Pengaruh Harga, Kualitas Produk Dan Promosi Terhadap Keputusan Pembelian. Universitas Pandanaran, Jurnal Ekonomi dan Bisnis Vol 6. No1.
} 
mereka inginkan dengan mudah dan mendapatkan lebih dari apa yang mereka inginkan selama ini. ${ }^{11}$

Upaya peningkatan kualitas pelayanan yang diberikan Bank Syariah harus berorientasi pasar atau masyarakat sebagai pengguna jasa perbankan. Hal ini berkaitandengan harapan masyarakat, mereka ingin mendapatkan hubungan yang baik dengan bank yang nyaman dan mudah melakukan transaksi.

Bagi perusahaan yang bergerak di bidang jasa perbankan, memuaskan nasabah adalah hal pokok yang tidak boleh diabaikan, dimana kepuasan nasabah merupakan faktor yang sangat strategis dalam memenangkan persaingan , mempertahankan citra perusahaan di masyarakat luas. Kepuasan konsumen ditentukan oleh kualitas produk dan layanan ,untuk kepuasan konsumen terhadap layanan, ada dua hal pokok yang saling berkaitan erat yaitu harapan konsumen terhadap pelayanan dan persepsi konsumen terhadap kualitas pelayanan. Pelanggan selalu menilai suatu layanan yang diterima dibandingkan dengan apa yang diharapkan atau diinginkan.

\section{Bentuk-Bentuk Strategi Manajemen Pemasaran}

1. Produk (Product)

Didalam perbankan syariah produk bank syariah diindonesia dapat dikelompokkan menjadi tiga kelompok:

a. Produk penghimpunan dana, antara lain:

1. Prinsip Wadiah, dibagi menjadi 2, yaitu: Wadiah yad amanah \& Wadiah yad dhamanah.

2. Prinsip Mudharabah.

Berdasarkan aplikasinya, terdiri dari: Tabungan berjangka \& Deposito berjangka

Berdasarkan kewenangan terdiri dari: Mudharabah mutlaqah, Mudharabah muqayadah on balance sheet,Mudharabah muqayadah off balance sheet.

b. Produk penyaluran dana, antara lain.

\footnotetext{
${ }^{11}$ Lo, C.W., and Leow, C.S. 2014. Islamic Banking in Malaysia: A Sustainable Growth of the Consumer Market. International Journal of Trade Economics and Finance.Vol. 5, No. 6: hal. 526-529.
} 
1. Prinsip jual beli yaitu : Pembiayaan mudharabah, Bai salam, Bai istisna.

2. Prinsip sewa (ijarah).

3. Prinsip bagi hasil (syirkah).

c. Produk jasa yaitu : Al-hiwalah, Gadai (rahn),Al-qardh,Wakalah, Kafalah.

2. Harga (Price)

Harga merupakan sejumlah nilai yang harus dibayar konsumen untuk membeli atau menikmati barang atau jasa yang ditawarkan.

3. Tempat dan distribusi (Place)

Strategi distribusi penting dalam upaya perusahaan melayani konsumen tepat waktu dan tepat sasaran. Keterlambatan dalam penyaluran mengakibatkan perusahaan kehilangan waktu dan kualitas barang serta diambilnya kesempatan oleh pesaing. Oleh karena itu perusahaan harus memiliki strategi untuk mencapai target pasar dan menyelenggarakan fungsi distribusi yang berbeda-beda.

4. Promosi (Promotion)

Promosi adalah suatu komunikasi pemasaran, artinya aktivitas pemasaran yang berusaha menyebarkan informasi, mempengaruhi dan meningkatkan pasar sasaran atas perusahaan dan produknya agar bersedia menerima, membeli dan loyal pada produk yang ditawarkan perusahaan yang bersangkutan. Ada 5 jenis kegiatan promosi, yaitu: Periklanan (Advertising),Promosi Penjualan, Publisitas, Penjualan Pribadi (Personal Selling), Orang (People). 


\section{BAB III}

\section{PENUTUP}

\section{Kesimpulan}

Manajemen strategi merupakan suatu proses yang dilakukan oleh manajemen dengan mengacu pada ketetapan yang telah ditetapkan sebelumnya dalam rangka untuk mencapai tujuan. Dengan kata lain manajemen strategi dapat diartikan sebagai sebuah seni dan ilmu dalam hal suatu rencana yang disusun dan dikelola dengan memperhitungkan berbagai sisi dengan tujuan memberikan dampak positif bagi organisasi secara jangka panjang. Jenis-jenis strategi perbankan syariah diantaranya adalah Strategi Perbankan Syariah Dari Sisi Sumber Daya Manusia (SDM), Strategi Perbankan Syariah Dari Sisi Keuangan, Strategi Perbankan Syariah Dari Aspek Pemasaran, Strategi Perbankan Syariah Dari Aspek Produksi Layanan Jasa. Dan adapun Bentuk-Bentuk Strategi Manajemen Pemasaran diantaranya, Produk (Product), Harga (Price). Tempat dan distribusi (Place), Promosi (Promotion). 


\section{DAFTAR PUSTAKA}

Andriansyah, Yuli. 2006. Kinerja Keuangan Perbankan Syariah di Indonesia dan Kontribusinya bagi Pembangunan Nasional. Jurnal Ekonomi Islam.Vol. 3, No. 2 : hal. 182-196.

Asnaini. 2008. Pengembangan Mutu SDM Perbankan Syariah: Sebagai Upaya Pengembangan Ekonomi islam. La_Riba, Jurnal Ekonomi Islam. Vol.II, No.1: pp. 51-68.

Asri Fajar Sari (2012). "Pengaruh Harga, Kualitas Produk Dan Promosi Terhadap Keputusan Pembelian. Universitas Pandanaran, Jurnal Ekonomi dan Bisnis Vol 6. No1.

Edi Suharto. 2006. Membangun Masyarakat Memberdayakan Rakyat. Bandung: PT Refika Aditama

Gregory G. Dess and G. T. Lumpkin, Strategic Management: Creating Competitive Advantage (Boston: McGraw Hill-Irwin, 2003).

Hasibuan, Malayu S. P. 2000. Manajemen Sumber Daya Manusia. Bumi Aksara: Jakarta.

J. David Hunger dan Thomas L. Wheelen, Manajemen Strategis (Yogyakarta: Andi, 1996), 4.

Jogiyanto, Sistem Informasi Strategik (Yogyakarta: Andi, 2005), 32.

Lo, C.W., and Leow, C.S. 2014. Islamic Banking in Malaysia: A Sustainable Growth of the Consumer Market. International Journal of Trade Economics and Finance.Vol. 5, No. 6: hal. 526-529.

Sondang P. Siagian. 2006. Manajemen Sumber Daya Manusia. Edisi Pertama. Bumi Aksara: Jakarta.

Yosal Iriantara, Manajemen Strategis Public Relations (Jakarta: Ghalia Indonesia, 2004), 12.

https://jamberita.com/read/2020/09/08/5961711/strategi-pemasaran-produk-bank-syariah-di-

indonesia/

https://ahliperbankan.com/strategi-pemasaran-bank-syariah/ 